\title{
OPTIMASI JENIS DAN KADAR SUMBER NITROGEN SERTA pH MEDIUM UNTUK PRODUKSI PROTEASE DARI ISOLAT HTCUM6.2.2 DARI TAUCO SURABAYA
}

\author{
Monika Rahayu dan *Evi Susanti \\ Jurusan Kimia FMIPA \\ Universitas Negeri Malang \\ *email: evi.susanti.fmipa@um.ac.id
}

Received 26 Oktober 2017

Accepted 28 Nopember 2017

\begin{abstract}
Abstrak
Penelitian ini bertujuan untuk mengetahui sumber nitrogen, kadar sumber nitrogen dan $\mathrm{pH}$ optimum untuk produksi protease isolat $\mathrm{HTcUM}_{6.2 .2}$. Penelitian ini merupakan penelitian eksperimental laboratoris menggunakan Rancangan Acak Lengkap (RAL) satu faktorial masing-masing yaitu jenis, kadar sumber nitrogen, serta $\mathrm{pH}$ medium dengan tahap penelitian terdiri dari peremajaan, validasi kemurnian isolat $\mathrm{HTcUM}_{6.2 .2}$, produksi ekstrak kasar protease isolat $\mathrm{HTcUM}_{6.2 .2}$, uji aktivitas protease. Hasil penelitian menunjukkan sumber nitrogen optimum untuk menghasilkan protease dari isolat HTcUM $_{6.2 .2}$ adalah susu skim dan limbah cair tahu. Kadar limbah cair tahu optimum untuk produksi protease dari isolat $\mathrm{HTcUM}_{6.2 .2}$ sebesar $10 \%$. Produksi protease cukup tinggi dan relatif konstan antara pH 6 sampai 8. Aktivitas protease tertinggi sebesar $0,817 \mathrm{U} / \mathrm{ml}$ dicapai dengan penggunaan $10 \%(\mathrm{v} / \mathrm{v})$ limbah cair tahu pada medium produksi, $\mathrm{pH}=7$ selama 3 hari.
\end{abstract}

Katakunci: protease, tauco, isolat, nitrogen, limbah cair tahu

\begin{abstract}
This study aims to determine the optimum of the nitrogen source, percentage of nitrogen source and $\mathrm{pH}$ for the production of protease from isolate HTcUM6.2.2. This research is a laboratory experimental with a research stage comprising inoculation and validation of the purity of the isolates $\mathrm{HTcUM}_{6.2 .2}$, production of crude extract of protease to determine source of nitrogen, percentage of nitrogen source and $\mathrm{pH}$ optimum, determination of protease activity. The results showed that the optimum source of nitrogen to produce proteases from the $\mathrm{HTcUM}_{6.2 .2}$ isolate was skim milk and tofu wastewater. Percentage of nitrogen source optimum to produce protease of $\mathrm{HTcUM}_{6.2 .2}$ isolate was $10 \%$ of tofu wastewater. Protease production is relatively high and constantance at $\mathrm{pH} 6$ to 8 . The highest protease activity was achieved by the use of $10 \%(\mathrm{v} / \mathrm{v})$ tofu wastewater at production medium, $\mathrm{pH}=7$ for 3 days was $0,817 \mathrm{U} / \mathrm{mL}$.
\end{abstract}

The keywords: protease, tauco, isolate, nitrogen, tofu wastewater

\section{Pendahuluan}

Protease merupakan salah satu enzim yang banyak diproduksi secara komersial pada berbagai industri, antara lain industri makanan, farmasi, deterjen, dan diagnostik. Porcine pepsin atau pepsin dari lambung babi adalah protease yang digunakan untuk proses produksi kolagen (Yang \& Shu, 2014), khususnya di negaranegara produsen kolagen seperti Amerika Utara, Eropa, dan Asia Pasifik. Padahal Indonesia mengimpor kolagen sekitar 
2.715.782 kg per tahun dari negara-negara tersebut (BPS, 2016). Hal ini menyebabkan timbulnya keraguan akan kehalalan kolagen tersebut. Mengatasi hal ini Ramadhan (2016) telah mengisolasi dan menyeleksi isolat bakteri potensial sebagai sumber protease dari pangan fermentasi tauco yang diharapkan dapat digunakan untuk isolasi kolagen dari sisik ikan bandeng sebagai pengganti porcine pepsin yaitu $\mathrm{HTcUM}_{2}, \quad \mathrm{HTcUM}_{6.2 .1}$, HTcUM $_{6.2 .2}$, dan HTcUM 10 .

Satu dari keempat isolat tersebut $\left(\mathrm{HTcUM}_{10}\right)$ menunjukkan aktivitas protease yang rendah yaitu sebesar 0,11 $\mathrm{U} / \mathrm{mL}$ dalam medium produksi yang mengandung sumber nitrogen pepton. Padahal isolat tersebut memiliki indeks proteolitik yang cukup tinggi dalam media Susu Skim Agar (SSA). Sumber nitrogen pepton yang digunakan dalam medium produksi tersebut diduga tidak dapat menginduksi produksi protease isolat tersebut. Beberapa penelitian melaporkan bahwa bakteri spesies yang sama menghasilkan aktivitas protease yang berbeda-beda dalam sumber nitrogen yang berbeda. Chu (2007) melaporkan bahwa Basillus subtilis menghasilkan protease optimum pada medium produksi yang mengandung sumber nitrogen berupa pepton $(836,3 \mathrm{U} / \mathrm{mL})$, sedangkan Ahmed et al. (2010) melaporkan bahwa Basillus subtillis menghasilkan protease lebih tinggi pada medium produksi yang mengandung sumber nitrogen berupa susu skim $(154.05 \pm 1.21 \mathrm{U} / \mathrm{mL})$ dibandingkan dengan kasein $(149.85 \pm 1.11 \mathrm{U} / \mathrm{mL})$.

Senyawa yang digunakan sebagai sumber nitrogen dapat berupa garamgaram anorganik seperti kalium nitrat, amonium sulfat, dan amonium nitrat maupun senyawa-senyawa organik dari bahan yang mengandung protein seperti pepton, ekstrak khamir, tripton, dan urea. (Pelczar \& Chan, 2010: 132-137). Masingmasing sumber nitrogen organik memiliki kadar dan kandungan protein yang khas. Kacang-kacangan pada proses perkecambahan memiliki kadar protein sekitar 20-25 \% berat kering. Tiyono (2011) juga menyatakan bahwa dalam biji kacang hijau mengandung protein sebesar $22,8 \%$, sedangkan biji kedelai sebesar $40 \%$ (Suhaidi, 2003). Limbah cair tahu mengandung protein sebesar $45 \%$ (Ounis et al., 2008). Kandungan protein utama dalam susu skim adalah kasein mencapai 3,7\% (Buckle et al. 1987). Pepton merupakan hasil hidrolisis dari suatu bahan yang mengandung protein melalui proses enzimatik. Bahan tersebut dapat berasal dari daging, ikan, kasein, gelatin, keratin, tepung kedelai, khamir dan lainlain (Nurhayati et al., 2015).

Produksi protease tidak hanya dipengaruhi oleh sumber nutrien yang terkandung pada media produksi, tetapi juga dipengaruhi oleh kondisi pertumbuhan seperti $\mathrm{pH}$ medium. Masingmasing bakteri memiliki $\mathrm{pH}$ optimum yang berbeda-beda tergantung jenis bakterinya. Jika bakteri ditumbuhakan diluar $\mathrm{pH}$ optimumnya, maka akan menurunkan pertumbuhan bakteri. Penurunan pertumbuhan bakteri menyebabkan produksi metabolit termasuk protease menurun. Isolat $\mathrm{HTcUM}_{6.2 .2}$ memiliki indeks proteolitik yang tinggi, diduga dapat menghasilkan aktivitas yang tinggi pada media produksi dengan sumber nitrogen dan kondisi pertumbuhan yang optimum

\section{Metode Penelitian}

\section{Alat dan Bahan}

Penelitian ini menggunakan alat-alat berupa peralatan gelas dan peralatan khusus yaitu magnetic stirrer, kawat ose ujung lingkaran, autoklaf, oven, Eyela soft incubator SLI-600ND, waterbath inkubator Memmert, Eyela Uni Termo Shaker NTS 1300, neraca analitik ACIS, vortex, enkas, centrifuge kokusan, Thermo Scientific Heraus Pico 17 Centrifuge, Thermo Scientific Hot Plate Stirrer, dan Bio Rad Smartspec Plus Spectrofotometer. Bahan-bahan yang digunakan dalam penelitian ini berderajat p.a. (pro analisis) yaitu: Natrium Klorida $(\mathrm{NaCl})$, Natrium 
Hidroksida $(\mathrm{NaOH})$, Natrium Karbonat $\left(\mathrm{Na}_{2} \mathrm{CO}_{3}\right)$, Folin Ciocalteu, Buffer fosfat pH 750 mM, BSA (Bovine Serum Albumin) , glukosa, pepton oxoid, magnesium sulfat heksahidrat $\left(\mathrm{MgSO}_{4} .7 \mathrm{H}_{2} \mathrm{O}\right)$, kalium dihidrogen fosfat $\left(\mathrm{KH}_{2} \mathrm{PO}_{4}\right)$, besi (II) sulfat heksahidrat $\left(\mathrm{FeSO}_{4} .7 \mathrm{H}_{2} \mathrm{O}\right)$, tembaga (II) sulfat pentahidrat $\left(\mathrm{CuSO}_{4} .5 \mathrm{H}_{2} \mathrm{O}\right)$, natrium sitrat dihidrat $\left(\mathrm{Na}_{3} \mathrm{C}_{6} \mathrm{H}_{5} \mathrm{O}_{7} .2 \mathrm{H}_{2} \mathrm{O}\right)$, tirosin, TCA (Asam trikloroasetat), kasein, dan baktoagar. Bahan-bahan berderajat teknis antara lain susu skim, bubuk kedelai, rebusan kecambah, limbah cair tahu, akuades, alkohol dan spiritus.

\section{Peremajaan isolat HTcUM6.2.2}

Peremajaan isolat HTcUM $_{6.2 .2}$ dilakukan dengan mengambil satu koloni tunggal dari isolat induk HTcUM $\mathrm{H}_{6.2 .2}$ dan distreak empat kuadran pada media Susu Skim Agar (SSA).

Optimasi jenis sumber nitrogen untuk produksi ekstrak kasar protease

Metode isolasi protease dengan optimasi jenis sumber nitrogen menggunakan jenis sumber nitrogen berupa pepton oxoid, susu skim, kasein, bubuk kedelai, rebusan kecambah, dan limbah cair tahu. Isolasi protease dan pengukuran aktivitas mengacu pada penelitian Alnahdi (2012) dengan modifikasi. Sebanyak 1 ose koloni tunggal bakteri dari isolat $\mathrm{HTcUM}_{6.2 .2}$ yang telah murni diinokulasikan ke dalam $100 \mathrm{~mL}$ medium produksi yang mengandung $(\mathrm{g} / \mathrm{mL}) \quad 0,5 \quad \mathrm{MgSO}_{4} .7 \mathrm{H}_{2} \mathrm{O} ; \quad 0,5$ $\mathrm{FeSO}_{4} .7 \mathrm{H}_{2} \mathrm{O} ;$ dan $0,5 \quad \mathrm{KH}_{2} \mathrm{PO}_{4} ; 0,5$ glukosa; untuk sumber nitrogen pepton, susu skim, kasein, dan bubuk kedelai 0,75; sedangkan untuk sumber nitrogen air rebusan kecambah dan limbah cair tahu $10 \% \mathrm{v} / \mathrm{v}$ pada $\mathrm{pH} 7$. Inokulum diinkubasi pada suhu $37{ }^{\circ} \mathrm{C}$ dengan agitasi $100 \mathrm{rpm}$ selama 72 jam. Setelah itu inokulum diambil $\pm 10 \mathrm{~mL}$ dan disentrifugasi pada $3000 \mathrm{rpm}$ selama 30 menit. Supernatan yang diperoleh merupakan ekstrak kasar enzim protease yang diuji aktivitas dan kadar proteinnya.

Optimasi kadar sumber nitrogen untuk produksi ekstrak kasar protease

Metode isolasi protease pada optimasi kadar sumber nitrogen dengan variasi kadar limbah cair tahu (v/v) 1\%, 5\%, 10\%, dan $15 \%$. Isolasi protease dan pengukuran aktivitas mengacu pada penelitian Alnahdi (2012) dengan modifikasi. Sebanyak 1 ose koloni tunggal bakteri dari isolat HTcUM $_{6.2 .2}$ yang telah murni diinokulasikan ke dalam $100 \mathrm{~mL}$ medium produksi yang mengandung $(\mathrm{g} / \mathrm{mL}) 0,5$ $\mathrm{MgSO}_{4} .7 \mathrm{H}_{2} \mathrm{O} ; \quad 0,5 \quad \mathrm{FeSO}_{4} .7 \mathrm{H}_{2} \mathrm{O} ; \quad 0,5$ $\mathrm{KH}_{2} \mathrm{PO}_{4} ; 0,5$ glukosa; dan sumber nitrogen menggunakan limbah cair tahu dengan variasi kadar (v/v) 1\%, 5\%, 10\%, dan $15 \%$ pada $\mathrm{pH}$ 7. Inokulum diinkubasi pada suhu $37{ }^{\circ} \mathrm{C}$ dengan agitasi $100 \mathrm{rpm}$ selama 72 jam. Setelah itu inokulum diambil $\pm 10 \mathrm{~mL}$ dan disentrifugasi pada $3000 \mathrm{rpm}$ selama 30 menit. Supernatan yang diperoleh merupakan ekstrak kasar enzim protease yang diuji aktivitas dan kadar proteinnya.

Optimasi pH medium untuk produksi ekstrak kasar protease

Metode isolasi protease dengan optimasi $\mathrm{pH}$ medium pada $\mathrm{pH} 4,5,6$, dan 7. Isolasi protease dan pengukuran aktivitas mengacu pada penelitian Alnahdi (2012) dengan modifikasi. Sebanyak 1 ose koloni tunggal bakteri dari isolat HTcUM $_{6.2 .2}$ yang telah murni diinokulasikan ke dalam $100 \mathrm{~mL}$ medium produksi yang mengandung $(\mathrm{g} / \mathrm{mL}) \quad 0,5$ $\mathrm{MgSO}_{4} .7 \mathrm{H}_{2} \mathrm{O} ; 0,5 \mathrm{FeSO}_{4} .7 \mathrm{H}_{2} \mathrm{O}$; dan 0,5 $\mathrm{KH}_{2} \mathrm{PO}_{4} ; 0,5$ glukosa; dan sumber nitrogen menggunakan limbah cair tahu $10 \% \mathrm{v} / \mathrm{v}$ dengan variasi $\mathrm{pH} \mathrm{4,} \mathrm{5,} \mathrm{6,} \mathrm{dan} 7$ dan 8 . Inokulum diinkubasi pada suhu $37{ }^{\circ} \mathrm{C}$ dengan agitasi $100 \mathrm{rpm}$ selama 72 jam. Setelah itu inokulum diambil $\pm 10 \mathrm{~mL}$ dan disentrifugasi pada $3000 \mathrm{rpm}$ selama 30 menit. Supernatan yang diperoleh merupakan ekstrak kasar enzim protease yang diuji aktivitas dan kadar proteinnya. 
Pembuatan kurva standar tirosin dengan metode anson

Sebanyak $2 \mathrm{~mL}$ larutan standar yang mengandung 0 (blanko), 10, 30, 50, dan 70 $\mu \mathrm{g} / \mathrm{mL}$ tirosin ditambahkan $5 \mathrm{~mL}$ larutan $0,5 \mathrm{M} \mathrm{Na}_{2} \mathrm{CO}_{3}$ dan $1 \mathrm{~mL}$ reagen Folin Ciocalteu. Larutan dihomogenkan dengan vortex kemudian diinkubasi pada $37{ }^{\circ} \mathrm{C}$ selama 30 menit. Kompleks berwarna biru yang terbentuk diukur absorbansinya pada panjang gelombang $660 \mathrm{~nm}$. Data konsentrasi tirosin dan absorbansinya digunakan untuk membuat kurva standar tirosin.

\section{Uji aktivitas protease}

Uji aktivitas protease merujuk pada penelitian Alnahdi (2012). Pengukuran aktivitas protease dilakukan dengan cara $0,5 \mathrm{~mL}$ substrat kasein $(1 \% \mathrm{~b} / \mathrm{v})$ dalam 50 $\mathrm{mM}$ buffer fosfat $\mathrm{pH} 7$ dimasukkan dalam tabung reaksi dan dicampur dengan $0,2 \mathrm{~mL}$ ekstrak kasar enzim, diinkubasi pada penangas air pada suhu $40{ }^{\circ} \mathrm{C}$ selama 20 menit, ditambahkan $1 \mathrm{~mL}$ TCA $(10 \% \mathrm{~b} / \mathrm{v})$, campuran dihomogenkan dengan vortex dan dijaga pada suhu ruang selama 15 menit. Campuran disentrifugasi pada $10.000 \mathrm{rpm}$ selama 10 menit. Supernatan yang dihasilkan dicampur dengan $2,5 \mathrm{ml}$ $\mathrm{Na}_{2} \mathrm{CO}_{3} \quad 0,4 \mathrm{M}$ dan ditambahkan $1 \mathrm{~mL}$ reagen Folin Cioceltau. Larutan dihomogenkan dengan vortex dan diinukbasi pada suhu kamar dalam ruang gelap selama 30 menit. Setelah itu, larutan hasil diukur absorbansi pada $660 \mathrm{~nm}$ dengan blanko menggunakan larutan tirosin standar. Kontrol mengikuti cara yang sama tetapi penambahan larutan TCA $(10 \% \mathrm{~b} / \mathrm{v})$ sebelum penambahan substrat kasein $(1 \% \mathrm{~b} / \mathrm{v})$ dalam $50 \mathrm{mM}$ buffer fosfat pH 7.

Aktivitas enzim dinyatakan dalam Unit (U), satu unit aktivitas enzim sama dengan banyaknya enzim yang dibutuhkan untuk menghasilkan 1 mikrogram tirosin setiap mililiter larutan per menit pada kondisi percobaan.Penentuan kadar tirosin ditentukan dengan cara hasil absorbansi sampel pada panjang gelombang $660 \mathrm{~nm}$ diinterpolasikan pada persamaan regresi kurva standar tirosin. Konsentrasi tirosin yang telah diketahui kemudian dimasukkan dalam persamaan untuk menghitung aktivitas enzim.. Berikut ini adalah persamaan yang digunakan:

$$
\text { Aktivitas enzim }(\mathrm{U} / \mathrm{mL})=\frac{C \times V_{e s}}{t \times V_{e}}
$$

dengan, $C$ (konsentrasi tirosin $(\mu \mathrm{g} / \mathrm{mL})$ ), Ves (volume total pengujian enzimsubstrat $(\mathrm{mL})=0,7 \mathrm{~mL}), t$ (waktu inkubasi enzim-substrat (menit)) dan $\mathrm{Ve}$ (volume enzim $(\mathrm{mL})=0,2 \mathrm{~mL})$

Pembuatan kurva standar protein dan pengukuran kadar protein dengan metode Lowry

Sebanyak 0,5 larutan protein standar yang mengandung 0 (blanko), 20, 40, 60, 80, $100 \mu \mathrm{g}$ BSA (Bovine Serum Albumin), ditambah 2,5 $\mathrm{mL}$ pereaksi biuret, diaduk hingga homogen. Campuran diinkubasi pada suhu kamar tepat 10 menit. Setelah itu campuran ditambahkan $0,25 \mathrm{~mL}$ Folin Ciocalteu, dihomogenkan dengan vortex, dan diinkubasi pada suhu kamar tepat 30 menit. Nilai absorbansi larutan diukur pada panjang gelombang $750 \mathrm{~nm}$. Data konsentrasi BSA dan absorbansinya digunakan untuk membuat kurva standar protein.

\section{Penentuan aktivitas spesifik protease}

Aktivitas spesifik dapat diukur dengan membandingan nilai aktivitas enzim per miligram protein ekstrak kasar selulernya. Jumlah protein dapat dihitung jika diketahui kadar atau konsentrasi protein dalam larutan enzim. Untuk penentuan kadar protein, hasil absorbansi sampel pada panjang gelombang $750 \mathrm{~nm}$ diinterpolasikan pada persamaan regresi kurva standar protein. Kadar atau konsentrasi protein yang telah diketahui kemudian dimasukkan dalam persamaan untuk menghitung aktivitas spesifik enzim. 


\section{Hasil dan Pembahasan}

\section{Peremajaan isolat HTCUM 6.2.2}

Peremajaan isolat HTcUM6.2.2 dilakukan dengan mengambil satu koloni dari isolat induk HTcUM6.2.2 dan distreak empat kuadran pada media SSA (Susu Skim Agar). Pertumbuhan bakteri protease pada media SSA dapat diamati dari terbentuknya zona bening disekitar koloni. Hal ini disebabkan bakteri tersebut menghidrolisis kasein susu yang awalnya berwarna putih keruh menjadi peptidapeptida dan asam-asam amino yang ditandai dengan adanya zona bening disekitar koloni (Pakpahan, 2009). Hasil dari peremajaan isolat $\mathrm{HTcUM}_{6.2 .2}$ dapat dilihat pada Gambar 1

Hasil peremajaan isolat HTcUM $_{6.2 .2}$ menghasilkan zona bening dengan diameter $1,12 \mathrm{~cm}$ dan diameter bakterinya sebesar $0,43 \mathrm{~cm}$ dengan waktu inkubasi pertumbuhan selama tiga hari. Berdasarkan perolehan data tersebut, isolat HTcUM $_{6.2 .2}$ mampu menghasilkan indeks proteolitik sebesar 2,60. Indeks proteolitik merupakan perbandingan diameter zona bening dengan diameter bakteri. Pengukuran indeks proteolitik diilustrasikan pada Gambar 2.

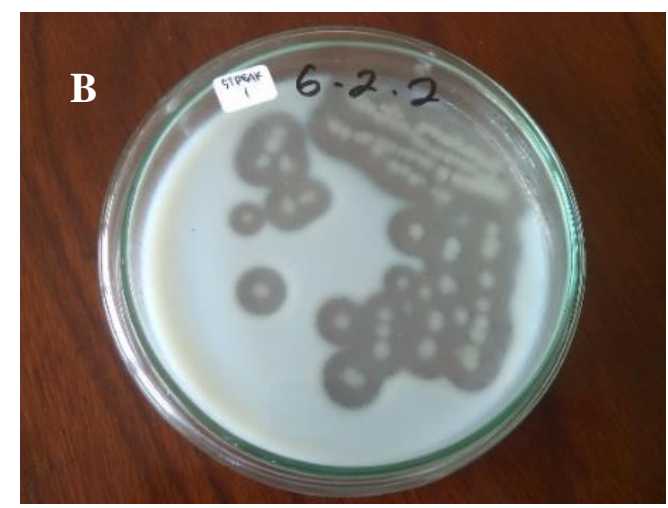

Gambar 1. Isolat induk HTcUM $\mathrm{H}_{6.2 .2}$ (A) dan hasil peremajaan isolat $\mathrm{HTcUM}_{6.2 .2}$ (B)

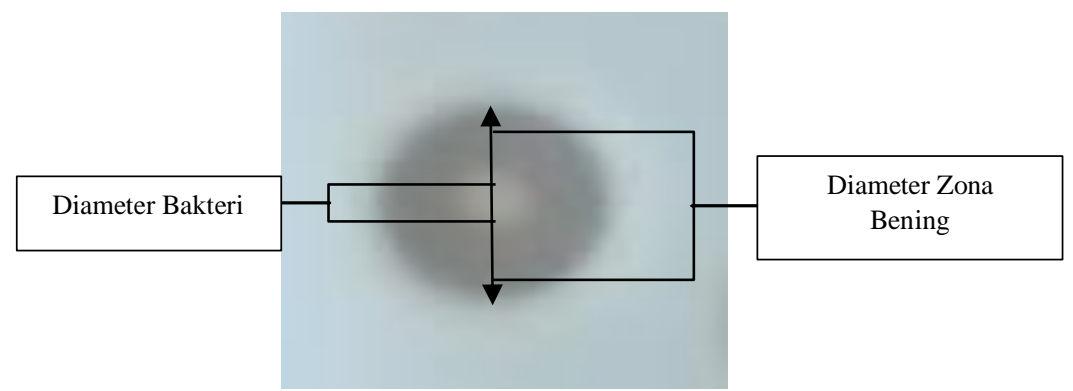

Gambar 2. Pengukuran Diameter Zona Bening dan Bakteri Hasil Hidrolisis Kasein Susu oleh Bakteri

Optimasi Jenis Sumber Nitrogen untuk Produksi Protease dari Isolat HTcUM 6.2 .2

Bakteri memerlukan sumber nutrisi untuk proses metabolismenya. Sumber nutrisi tersebut berasal dari senyawa nitrogen, karbon, dan senyawa lain. Pada penelitian ini digunakan sumber nitrogen berupa senyawa-senyawa organik murni seperti kasein dan pepton juga sumber nitrogen yang berasal dari bahan alamiah seperti susu skim, bubuk kedelai, air rebusan kecambah dan limbah cair tahu. Pemilihan sumber nitrogen tersebut karena isolat $\mathrm{HTcUM}_{10}$ yang diisolasi dari tauco menghasilkan aktivitas protease yang rendah dalam medium produksi yang 
mengandung sumber nitrogen pepton (Ramadhan, 2016), maka pepton digunakan sebagai variabel pembanding.

Pertumbuhan bakteri dapat diamati berdasarkan perubahan jumlah sel maupun produksi metabolit primernya seperti protein. Naiola (2002) melaporkan bahwa aktivitas protease bakteri penghasil protease mulai meningkat setelah hari ke tiga dan stabil pada hari ke 4-6. Aktivitas protease isolat $\mathrm{HTcUM}_{6.2 .2}$ ditunjukkan pada Gambar 3. Aktivitas protease isolat HTcUM $_{6.2 .2}$ tertinggi pada hari ketiga dalam semua jenis sumber nitrogen yang digunakan dan menurun secara signifikan pada hari keempat.

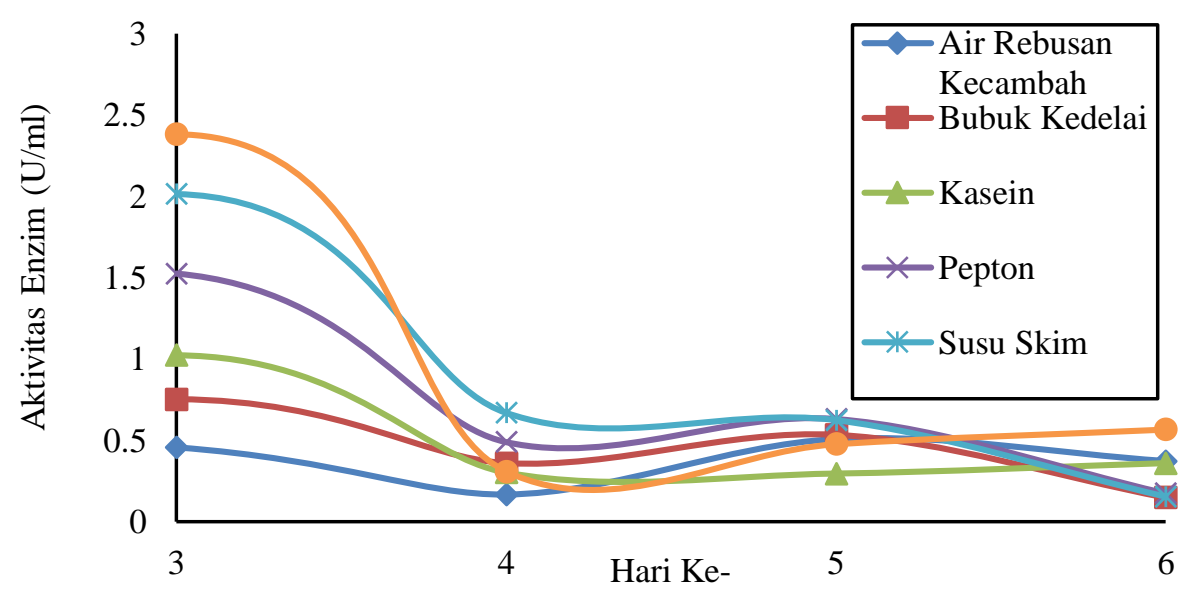

Gambar 3. Aktivitas protease Isolat HTcUM $\mathrm{H}_{6.2}$ pada hari ke-3,4,5 dan 6 dalam media produksi dengan sumber nitrogen yaitu: air rebusan kecambah, bubuk kedelai, kasein, pepton, susu skim, limbah cair tahu.

Jenis sumber nitrogen dalam masingmasing media produksi mempengaruhi jumlah protein terlarut (Tabel 1). Bubuk kedelai, susu skim, kasein dan pepton memiliki kadar protein terlarut rendah. Protein dalam bubuk kedelai yang berupa tepung, kasein dan pepton diduga mengandung protein yang kurang larut dalam air. Air rebusan kecambah dan limbah cair tahu memiliki kadar protein terlarut yang paling tinggi. Hal tersebut diduga karena pada proses perebusan kecambah melarutkan protein yang terkandung didalam kecambah. Limbah cair tahu merupakan filtrat hasil penyaringan koagulan dari fermentasi susu kedelai sehingga diduga banyak mengandung protein berupa polipeptida pendek yang lebih larut di dalam air dibandingkan protein berukuran besar seperti pepton maupun kasein

Tabel 1. Kadar protein terlarut dalam bubuk kedelai, susu skim, kasein, pepton, limbah cair tahu, dan air rebusan kecambah

\begin{tabular}{cc}
\hline Jenis Sumber Nitrogen & Kadar Protein Terlarut $(\mathbf{m g} / \mathbf{m L})$ \\
\hline Bubuk Kedelai & 1,835 \\
Susu Skim & 2,356 \\
Kasein & 2,388 \\
Pepton & 2,833 \\
Limbah Cair Tahu & 3,245 \\
Air Rebusan Kecambah & 3,532 \\
\hline
\end{tabular}


Hasil penelitian menunjukkan jenis sumber nitrogen sangat mempengaruhi aktivitas spesifik protease relatif yang dihasilkan dari isolat HTcUM6.2.2 (Gambar 4). Aktivitas spesifik protease relatif merupakan aktivitas enzim dibagi dengan kadar protein terlarutnya. Aktivitas protease relatif isolat $\mathrm{HTcUM}_{6.2 .2}$ dengan sumber nitrogen air rebusan kecambah paling rendah hanya sebesar $0,130 \mathrm{U} / \mathrm{mg}$ padahal air rebusan kecambah memiliki kadar protein terlarut tertinggi. Air rebusan kecambah diperoleh dengan merebus kecambah dalam air mendidih selama 10 menit, diduga protein yang terlarut dari proses ini masih merupakan protein komplek dengan rantai polipeptida yang panjang sehingga bakteri membutuhkan waktu yang lebih lama dalam mencerna protein-protein yang masih kompleks tersebut sebagai sumber nutrien untuk proses pertumbuhan termasuk produksi proteasenya.

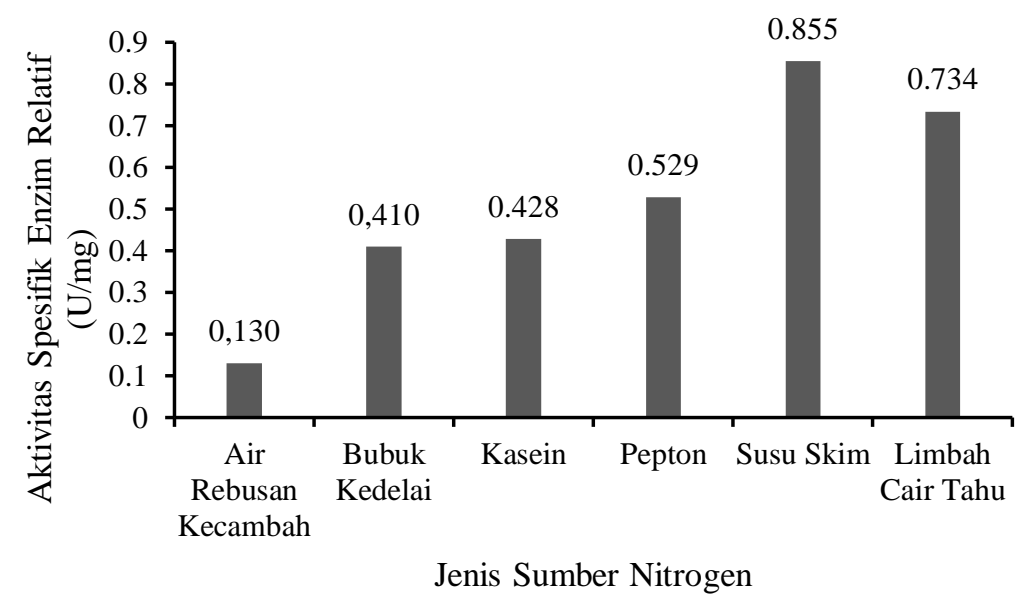

Gambar 4. Aktivitas protease spesifik relatif isolat $\mathrm{HTcUM}_{6.2 .2}$ dalam berbagai jenis sumber nitrogen

Aktivitas protease spesifik relatif yang dihasilkan dalam medium produksi dengan sumber nitrogen bubuk kedelai, kasein dan pepton memiliki aktivitas protease dengan kategori sedang. Aktivitas protease spesifik relatif dengan sumber nitrogen pepton memiliki aktivitas yang lebih tinggi $(0,529 \mathrm{U} / \mathrm{mg})$ dibandingkan kasein $(0,428$ $\mathrm{U} / \mathrm{mg})$ dan bubuk kedelai $(0,410 \mathrm{U} / \mathrm{mg})$. Hal ini disebabkan pepton merupakan hasil hidrolisis protein hewani, sehingga panjang rantai polipeptidanya lebih bendek daripada kasein maupun protein yang terdapat dalam bubuk kedelai. Aktivitas spesifik protease yang tertinggi dihasilkan dalam medium produksi yang mengandung sumber nitrogen berupa susu skim $(0,855 \mathrm{U} / \mathrm{mg})$ dan limbah cair tahu $(0,734)$. Susu skim dan limbah cair tahu merupakan sumber nitrogen alamiah yang lebih kaya nutrisi dibandingkan sumber nitrogen lainnya. Susu skim selain mengandung protein utama berupa kasein juga mengandung beberapa protein lain, laktosa, dan beberapa asam lemak. Limbah cair tahu merupakan filtrat penyaringan koagulan hasil fermentasi susu kedelai diduga mengandung berbagai nutrisi lain yang lebih mudah dicerna seperti oligosakarida dan polipeptida pendek. Isolat HTcUM6.2.2 mampu menghasilkan protease tertinggi dalam media produksi mengandung susu skim, tetapi untuk pengembangan ke skala industri maka penggunaan susu skim kurang efisien secara ekonomis karena harga media produksi menjadi sangat mahal. Limbah cair tahu lebih potensial digunakan sebagai sumber nitrogen karena ditinjau dari nilai ekonomis. Protease yang dihasilkan dalam media produksi cukup sebanding dengan protease yang dihasilkan dalam medium 
mengandung susu skim. Jumlah limbah cair tahu melimpah karena banyaknya industri tahu yang ada di Kota Malang sehingga mudah didapatkan dan tidak termanfaatkan.

Optimasi Kadar Sumber Nitrogen untuk Produksi Protease dari Isolat HTcUM6.2.2

Optimasi produksi protease dari isolat HTcUM $_{6.2 .2}$ pada tahap ini dilakukan dengan memvariasikan kadar sumber nitrogen yang terdapat dalam medium produksi. Aktivitas protease hasil optimasi kadar sumber nitrogen disajikan pada Tabel 2. Peningkatan jumlah limbah cair tahu dalam medium produksi sebanding dengan peningkatan kadar proteinnya. Hal ini menunjukkan bahwa dengan kadar sumber nitrogen yang semakin tinggi maka pertumbuhan bakteri juga semakin tinggi.

Tabel 2. Aktivitas Protease Hasil Optimasi Kadar Sumber Nitrogen

\begin{tabular}{ccccc}
\hline \multicolumn{2}{c}{ Medium Produksi } & \multicolumn{3}{c}{ Enzim } \\
$\begin{array}{c}\text { Kadar } \\
\text { Limbah Cair } \\
\text { Tahu }(\%)\end{array}$ & $\begin{array}{c}\text { Kadar } \\
\text { Protein } \\
\text { Terlarut } \\
(\mathrm{mg})\end{array}$ & $\begin{array}{c}\text { Aktivitas } \\
\text { Enzim } \\
(\mathrm{U} / \mathrm{mL})\end{array}$ & $\begin{array}{c}\text { Kadar Protein } \\
(\mathrm{mg} / \mathrm{mL})\end{array}$ & $\begin{array}{c}\text { Aktivitas Spesifik } \\
\text { Enzim } \\
(\mathrm{U} / \mathrm{mg})\end{array}$ \\
\hline 1 & 0,325 & $0,051 \pm 0,000$ & $0,022 \pm 0,004$ & $2,381 \pm 0,397$ \\
5 & 1,623 & $0,154 \pm 0,073$ & $0,047 \pm 0,000$ & $3,279 \pm 1,555$ \\
10 & 3,245 & $0,817 \pm 0,118$ & $0,070 \pm 0,006$ & $11,65 \pm 1,834$ \\
15 & 4,868 & $0,071 \pm 0,064$ & $0,104 \pm 0,004$ & $0,664 \pm 0,576$ \\
\hline
\end{tabular}

Namun hubungan tersebut tidak linier pada aktivitas enzim. Peningkatan jumlah limbah cair tahun meningkatkan aktivitas protease yang dihsilkan hingga penggunaan $10 \%$, tetapi pada kadar diatasnya yaitu $15 \%$ aktivitas protease menurun drastis. Hal ini kemungkinan pada kondisi tersebut terdapat senyawa yang dapat menghambat ekpresi gen protease, sehingga walaupun jumlah protein ekstrak selular meningkat tetapi aktivitas protease yang dihasilkan menurun. Hal ini dikuatkan oleh nilai aktivitas spesifik protease yang juga menurun drastis pada penggunaan limbah cair tahu sebesar $15 \%$. Maka penggunaan $10 \%$ limbah cair tahu mampu menghasilkan protease optimum dari isolat HTcUM $_{6.2 .2}$ dengan nilai aktivitas enzim sebesar $0,817 \pm 0,118 \mathrm{U} / \mathrm{mL}$ dan aktivitas spesifik enzim sebesar 11,65 $\pm 1,834$ $\mathrm{U} / \mathrm{mg}$.

\section{Optimasi pH Medium untuk Produksi Protease dari Isolat HTcUM6.2.2}

Secara umum, $\mathrm{pH}$ medium mempengaruhi pertumbuhan bakteri.
Pertumbuhan bakteri sejalan dengan aktivitas yang dihasilkan. Setiap enzim memiliki $\mathrm{pH}$ medium optimum yang bervariasi. Pada $\mathrm{pH}$ medium optimumnya, aktivitas enzim yang dihasilkan lebih tinggi dari $\mathrm{pH}$ lainnya. Produksi protease dari isolat $\mathrm{HTcUM}_{6.2 .2}$ dilakukan dengan variasi $\mathrm{pH}$ medium pada $\mathrm{pH} 4,5,6,7$, dan 8 untuk mengetahui $\mathrm{pH}$ optimum aktivitasnya seperti yang ditunjukkan Gambar 5.

Isolat HTcUM6.2.2 menghasilkan aktivitas protease yang relatif rendah pada $\mathrm{pH} 4$ dan 5, dan relatif tinggi pada $\mathrm{pH} 6,7$, dan 8. Bahkan pada $\mathrm{pH} 6,7$ dan 8 , besarnya aktivitas protease yang dihasilkan tidak berbeda secara signifikan. Berdasarkan hasil ini diduga isolat HTcUM $_{6.2 .2}$ merupakan bakteri proteolitik netral. Sifat ini membawa keuntungan bahwa penjagaan kondisi $\mathrm{pH}$ untuk produksi protease isolat $\mathrm{HTcUM}_{6.2 .2}$ tidak terlalu ketat pada suatu $\mathrm{pH}$ tertentu tetapi ada dalam suatu rentang yang cukup lebar yaitu 6 hingga 8 


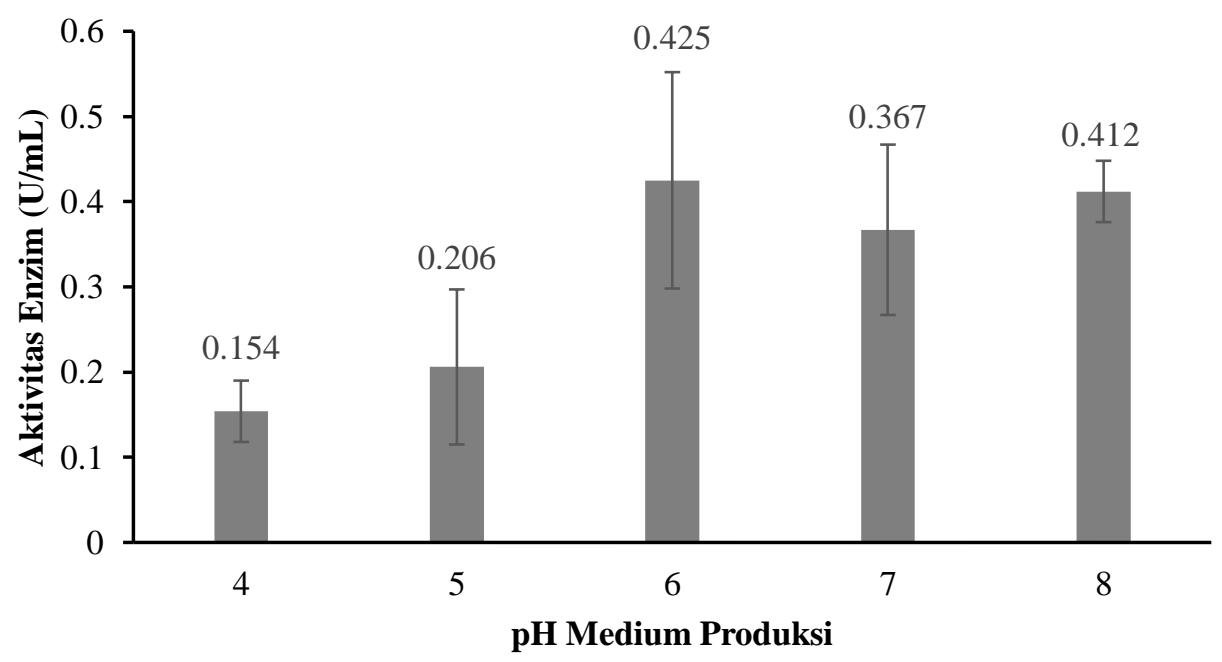

Gambar 5. Aktivitas protease isolat $\mathrm{HTcUM}_{6.2 .2}$ pada berbagai variasi $\mathrm{pH}$

\section{Kesimpulan}

Jenis sumber nitrogen terbaik untuk produksi protease dari isolat $\mathrm{HTcUM}_{6.2 .2}$ adalah susu skim dan limbah cair tahu, tetapi limbah cair tahu lebih potensial digunakan sebagai sumber nitrogen karena lebih murah dan mudah diperoleh. Kadar

\section{Daftar Pustaka}

Ahmed, I., Irfan M., Nadeem, M., Zia M. A., Ahmad B. A. \& Iqbal H. M. N. 2010. Optimization of Media and Environmental Conditions for Alkaline Protease Production Using Bacillus Subtilis in Submerged Fermentation Process. Journal of IJAVMS, 4 (4) :105-113.

Alnahdi, H. S. 2012. Isolation and screening of extracellular proteases produced by new isolated Bacillus sp environmental samples and screened their capability of protease. Journal of Applied Pharmaceutical Science, 2 (9): 71-74.

Badan Pusat Statistik Kabupaten Sidoarjo. 2016. Statistik Daerah Kabupaten Sidoarjo, (Online), (https://www.scribd.com/document/3 27540037/Statistik-Daerah-Kabupa ten-Sidoarjo-2016), diakses 12 Maret 2017. limbah cair tahu optimum untuk produksi protease dari isolat $\mathrm{HTcUM}_{6.2 .2}$ yaitu $10 \%$. Aktivitas protease tertinggi sebesar 0,817 $\mathrm{U} / \mathrm{ml}$ dicapai dengan penggunaan $10 \%$ limbah cair tahu pada medium produksi, $\mathrm{pH}=7$ selama 3 hari.

Buckle, K.A., Edward, R.A., Fleet, G.H. \& Wooton, M. 1987. Ilmu Pangan. Diterjemahkan oleh H. Purnomo \& Adiono. Jakarta: Penerbit Univesitas Indonesia.

Chu, W. 2007. Optimization of extracellular alkaline protease production from species of Bacillus. Journal of $J$ Ind Microbiol Biotechnol, 34 : 241-245.

Naiola, E. \& Widhyastuti, N. 2002. Isolasi, seleksi dan optimasi produksi protease dari beberapa isolat bakteri. Jurnal Berita Biologi, 6 (3): 467-473.

Nurhayati, T., Ibrahim, B., Suptijah, P., Salamah, E., Fitra, R. N., Astuti, E. R. W. 2015. Karakterisasi Pepton Ikan Hasil Tangkap Sampingan Tidak Layak Konsumsi sebagai Sumber Nutrien Pertumbuhan Mikroorganisme. Jurnal Teknologi Industri Pertanian, 25 (1) : 68-77. 
Ounis, W. B., Champagne, C. P., Makhlouf, J. \& Bazinet, L. 2008. Utilization of tofu whey pre-treated by electromembrane process as a growth medium for Lactobacillus plantarum LB17. Journal of Desalination, 229 : 192-203.

Pakpahan, R. 2009. Isolasi Bakteri dan Uji Aktivitas Protease Termofilik dari Sumber Air Panas Sipoholon Tapanuli Utara Sumatera Utara. Tesis tidak diterbitkan. Medan : Sekolah Pascasarjana Universitas Sumatera Utara.

Pelczar, M. J. Jr., \& Chan, E. C. S., 2010. Dasar-dasar mikrobiologi. Jakarta: UIPress

Ramadhan, H.R. 2016. Isolasi Bakteri Penghasil Protease dari Pangan Fermentasi Tauco sebagai Sumber Protease Untuk Isolasi Kolagen secara Enzimatis dari Sisik Ikan Bandeng. Skripsi tidak diterbitkan. Malang: S1 Kimia Universitas Negeri Malang.
Suhaidi, I. 2003. Pengaruh Lama Perendaman Kedelai dan Jenis Zat Penggumpal Terhadap Mutu Tahu. Sumatra Utara : Universitas Sumatra Utara.

Tiyono, A. 2010. Mempelajari Pengaruh Penambahan Beberapa Asam pada Proses Isolasi Protein terhadap Tepung Protein Isolat Kacang Hijau (Phaseolus radiatus L.). Seminar Rekayasa Kimia dan Proses, 4-5 Agustus 2010.

Yang, H. \& Shu, Z. 2014. The extraction of collagen protein from pigskin. Journal of Chemical and Pharmaceutical Research, 6 (2): 683687. 